\title{
Upaya Meningkatkan Kapasitas Hasil Biogas dengan Penambahan Stater Ragi
}

\author{
Arif Setyo Nugroho* \\ Program Studi Teknik Mesin, Sekolah Tinggi Teknologi Warga Surakarta \\ Jln. Raya Solo-Baki No.81C Kwarasan Grogol Dayung Sukoharo, 57552, Indonesia \\ E-mail: arifsetyon@atw.ac.id
}

\section{Info Naskah:}

Naskah masuk: 10 Juni 2020

Direvisi: 2 Agustus 2020

Diterima: 13 Agustus 2020

\begin{abstract}
Abstrak
Penelitian ini diharapkan dapat mengetahui cara meningkatkan produksi biogas. Upaya yang dilakukan dengan cara memvariasikan bahan pembuat biogas : Variasi bahan biogas adalah kotoran sapi $100 \%$, dan Ampas tebu : ragi dengan perbandingan volume 3:1, kotoran sapi + ampas tebu dengan perbandingan volume 3:1 ditambah ragi tape 100 gram. Pengujian menggunakan bahan sebanyak $4 \mathrm{~kg}$ dalam tabung kapasitas 6 liter. Hasilnya adalah bahan kotoran sapi ditambah dengan ampas tebu dan ragi tape menghasilkan biogas dengan jumlah sangat terbanyak bila dibandingkan dengan variasi lain paling banyak hasilnya. Jumlah total biogas yang berasal dari bahan kotoran sapi ditambah dengan ampas tebu dan ragi tape paling banyak yaitu sebanyak 5.6 liter dalam 10 hari, paling sedikit adalah kotoran sapi tanpa tambahan yaitu 1.67 liter dalam 10 hari. Produksi biogas paling banyak rata-rata hari ke 5-8, setelah itu mengalami penurunan di setiap variasi.
\end{abstract}

\section{Keywords:}

bagase;

biogas;

cow dung;

yeast tape.

\begin{abstract}
This research is expected to find out how to increase biogas production. Efforts are made by varying the ingredients for making biogas: Variations in biogas materials are $100 \%$ cow dung, and bagasse: yeast with a volume ratio of 3: 1, cow dung + bagasse with a volume ratio of 3: 1 plus 100 grams of tape yeast. The test uses $4 \mathrm{~kg}$ of material in a 6 liters capacity tube. The result is the material of cow dung coupled with bagasse and yeast tape produces the most amount of biogas when compared to other variations with the most results. The total amount of biogas originating from cow dung plus bagasse and tape yeast is at most 5.6 liters in 10 days, the least is cow dung without additional, namely 1.67 liters in 10 days. Biogas production is mostly on the 5-8 days on average, after that it has decreased in each variation.
\end{abstract}




\section{Pendahuluan}

Kebutuhan energi semakin meningkat seiring dengan meningkatnya jumlah manusia. Meningkatnya perkembangan jumlah manusia meningkat pula perkembangan industri. Semakin besar perkembangan industri mengakibatkan semakin besar kebutuhan energi, kebutuhan energi saat ini sebagian besar diperoleh dari energi fosil. Energi fosil di bumi mempunyai keterbatasan jumlah dan tidak dapat diperbarui. Pembakaran berbahan bakar fosil menimbulkan beberapa masalah terutama kenaikan suhu akibat meningkatnya emisi gas buang di atmosfer [1].

Beberapa metode dalam pembuatan bahan bakar dikembangkan untuk menggantikan kebutuhan bahan bakar fosil dengan bahan bakar terbarukan. Salah satu sumber energi terbarukan adalah kotoran sapi diolah menjadi gas yang mampu bakar, yang disebut biogas [2]. Pengolahan kotoran sapi dengan cara fermentasi didalam sebuah ruangan yang disebut digester dengan kondisi tanpa udara atau anaerob dengan bantuan bakteri, hasilnya adalah gas mampu bakar .

Bakteri hidup dan berkembang dengan cara membusukan bahan-bahan organik didalam digester. Bahan organik yang dapat diolah menjadi biogas antara lain limbah tahu, kotoran sapi dan enceng gondok. Hasil dan kualitas biogas tergantung dari besar kecilnya digester, temperatur ruangan, kelembaban dan tingkat keasaman. Hal tersebut dikondisikan dengan harapan bakteri dapat tumbuh dan berkembang, dan gas yang dihasilkan semakin banyak [3]. Biogas memiliki komponen gas utama yaitu $\mathrm{CH} 4$ dan $\mathrm{CO}_{2}$, selain itu ada juga gas lain seperti $\mathrm{N}_{2}, \mathrm{H}_{2}, \mathrm{H}_{2} \mathrm{~S}$, atau CO dengan persentase kecil [4].

Azhahri, Fajri dalam penelitiannya menjelaskan kualitas biogas pengujian dengan menggunakan kotoran sapi dan ditambah dengan buah buahan sebagai stater. Pada minggu ke 2 jumlah biogas dari semua variasi mengalami penurunan jumlahnya, tetapi yang menggunakan stater buah -buahan penurunan tidak begitu banyak [5]. Badiya HS $\mathrm{dkk}$, melakukan penelitian pembuatan biogas dengan tiga variasi, Variasi tersebut adalah ampas tebu $100 \%$, kotoran sapi $100 \%$ dan campuran kotoran sapi dan ampas tebu. Hasil pengujian menunjukan bahwa biogas dengan bahan baku kotoran sapi di campur dengan ampas tebu mennghasilkan volume biogas paling banyak yaitu sebesar $74 \mathrm{~cm} 3$, paling sedikit biogas berbahan baku ampas tebu sebanyak $33 \mathrm{~cm} 3$ dengan $\mathrm{pH}$ antara 4,6 sampai 6,6 [6] .

Yanto, H, meneliti biogas diproduksi dengan kombinasi ampas tebu dan kotoran sapi dengan rasio $\mathrm{C} / \mathrm{N}$ 25 pada minggu ke 2 menghasilkan biogas paling banyak diantara bahan dari rumen dan enceng gondok, tetapi semakin bertambahnya hari jumlah biogas menurun. Jumlah biogas naik dengan bahan baku rumen dengan rasio C/N 30 pada hari ke 30-45[7]. Janke, Leandro dkk, melakukan penelitian dengan berbagai macam bahan untuk pembuatan biogas. Bahan tersebut antara lain adalah jerami, ampas tebu, limbah makanan. Hasil biogas paling banyak adalah menggunakan ampas tebu [8] .

Dalam penelitiannya Sumardiono, Siswo dkk (2017) menjelaskan produksi biogas dengan hasil tertinggi adalah campuran kotoran sapi dicampur dengan ampas tebu, ampas tebu tidak boleh lebih dari $2 \%$ dari total berat campuran. Hasil lebih baik lagi bila ampas tebu di rendam dengan $\mathrm{NaOH}$ selama 24 jam [9]. Aldi Budi R dkk, melakukan percobaan dengan bahan baku biogas adalah kotoran sapi dan ampas tebu, Hasil terbanyak pada variasi campuran ampas tebu 25\%, kotoran sapi 10\% dan air 30\%, jumlah volume gas sebanyak $26,57 \mathrm{~L} / \mathrm{kg}$ substrat [10].

Penting untuk meningkatkan produksi biogas maka penelitian dengan bahan baku kotoran sapi ditambah ampas tebu dan ragi untuk dilakukan.

\section{Metode \\ 2.1 Biogas}

Tahapan pembentukan biogas adalah tahap hidrolisis, tahap permentasi, proses acetogenesis, metanogenesis. Tahap hidrolisis, dimana tahapan ini adalah tahapan awal dari proses pembentukan biogas. Prosesnya diawali dengan penguraian selulosa, hemiselulosa dan bahan ekstratif seperti protein, karbohidrat dan lipida. Enzim yang berperan dalam proses penguraian adalah selulose, amilase, protease dan lipase [11]. Contoh rantai pendek dalam proses pembentukan biogas adalah polisakarida terurai menjadi monosakarida, protein dirubah menjadi asam amino dan peptida. Reaksi nya adalah sebagai berikut[12].

$$
\left(\mathrm{C}_{6} \mathrm{H}_{10} \mathrm{O}_{5}\right) n+n \mathrm{H}_{2} \mathrm{O} \rightarrow n \mathrm{C}_{6} \mathrm{H}_{12} \mathrm{O}_{6}+n \mathrm{H}_{2}
$$

Reaksi (1) merupakan tahapan hidrolisis, dimana pada tahapan hidrolisis terjadi penguraian bahan yang mengandung selulosa, hemiselulosa, protein, karbohidrat dan lipida diurai menjadi senyawa rantai lebih pendek dan menghasilkan bakteri. Bakteri hidup, tumbuh dan berkembang di daerah yang asam. Bakteri sangat memiliki peran penting dalam pembuatan biogas, bakteri tersebut akan menghasilkan asam. Asam tersebut akan merubah rantai pendek hasil tahapan hidrolisis menjadi asam asetat, $\mathrm{H}_{2}$ dan $\mathrm{CO}_{2}$. Bakteri memerlukan oksigen dan karbon untuk menghasilkan asam, oksigen dan karbon yang diperlukan berasal dari cairan kotoran sapi atau air bersih. Bakteri juga berfungsi untuk menghasilkan alkohol, asam organik, asam amino, $\mathrm{CO}_{2}, \mathrm{H}_{2} \mathrm{~S}$ dan sedikit $\mathrm{CH}_{4}$ dengan cara mengubah senyawa molekul rendah.

Tahap fermentasi adalah terlarutnya senyawa yang terbentuk dalam proses hidrolisis terdegradasi dan dikonversi menjadi $\mathrm{CO}_{2}$ dan $\mathrm{H}_{2}$ oleh bakteri asidogenik (mikroorganisme fermentasi). Asam $\mathrm{CH}_{3} \mathrm{COOH}^{-}$adalah jenis asam organik yang digunakan sebagai substrat pembentuk $\mathrm{CH}_{4}$, reaksinya adalah sebagai berikut [13]:

$\mathrm{C}_{6} \mathrm{H}_{12} \mathrm{O}_{6} \leftrightarrow 2 \mathrm{CH}_{3} \mathrm{CH}_{2} \mathrm{OH}+2 \mathrm{CO}_{2}$

$\mathrm{C}_{6} \mathrm{H}_{12} \mathrm{O}_{6}+2 \mathrm{H}_{2} \leftrightarrow 2 \mathrm{CH}_{3} \mathrm{CH}_{2} \mathrm{COOH}+2 \mathrm{H}_{2} \mathrm{O}$

$$
\mathrm{C}_{6} \mathrm{H}_{12} \mathrm{O}_{6} \rightarrow 3 \mathrm{CH}_{3} \mathrm{COOH}
$$

Proses acetogenesis menghasilkan gas $\mathrm{H}_{2}$ yang terbentuk pada tahap asidogenik dari proses pencernaan anaerob, sehingga tahap ini juga dikenal sebagai tahap dehidrogenasi. Gas $\mathrm{H}_{2}$ dikonsumsi oleh bakteri penghasil 
$\mathrm{CH}_{4}$, dengan cara merubah $\mathrm{H}_{2}$ menjadi $\mathrm{CH}_{4}$. Reaksinya adalah sebagai berikut :

$$
\begin{gathered}
\mathrm{CH}_{3} \mathrm{CH}_{2} \mathrm{COO}^{-}+3 \mathrm{H}_{2} \mathrm{O} \leftrightarrow \mathrm{CH}_{3} \mathrm{COO}^{-}+\mathrm{H}^{+} \mathrm{HCO}_{3}^{-}+3 \mathrm{H}_{2} \\
\mathrm{C}_{6} \mathrm{H}_{12} \mathrm{O}_{6}+2 \mathrm{H}_{2} \mathrm{O} \leftrightarrow 2 \mathrm{CH}_{3} \mathrm{COOH}+2 \mathrm{CO}_{2}+4 \mathrm{H}_{2} \\
\mathrm{CH}_{3} \mathrm{CH}_{2} \mathrm{OH}+2 \mathrm{H}_{2} \mathrm{O} \leftrightarrow \mathrm{CH}_{3} \mathrm{COO}^{-}+3 \mathrm{H}_{2}+\mathrm{H}^{+}
\end{gathered}
$$

Reaksi yang terjadi adalah reaksi dua arah yang menunjukkan pelepasan $\mathrm{H}_{2}$. Persamaan (5) menunjukkan bahwa produk fase asam dikonversi menjadi asetat $\left(\mathrm{CH}_{3} \mathrm{COO}^{-}\right)$dan hidrogen $\left(\mathrm{H}_{2}\right)$, yang dapat digunakan oleh bakteri metanogenik pada tahap selanjutnya dari proses pencernaan anaerob, bakteri seperti Methanobacterium suboxydans dan Methanobacterium propionicum melakukan penguraian produk fase asam menjadi asetat dan $\mathrm{H}_{2}$ yang dilepaskan dalam reaksi menunjukkan efek toksik pada mikroorganisme [14].

Tahap keempat dari proses anaerob adalah metanogenesis. Pada tahap ini, bakteri mengubah $\mathrm{CH}_{3} \mathrm{COOH}$ dan $\mathrm{H}_{2}$ menjadi $\mathrm{CO}_{2}$ dan $\mathrm{CH}_{4}$ [12] .

$$
\begin{aligned}
\mathrm{CH}_{3} \mathrm{COOH} & \rightarrow \mathrm{CH}_{4}+\mathrm{CO}_{2} \\
\mathrm{CO}_{2}+4 \mathrm{H}_{2} & \rightarrow \mathrm{CH}_{4}+2 \mathrm{H}_{2} \mathrm{O} \\
2 \mathrm{CH}_{3} \mathrm{CH}_{2} \mathrm{OH}+\mathrm{CO}_{2} & \rightarrow \mathrm{CH}_{4}+2 \mathrm{CH}_{3} \mathrm{COOH}
\end{aligned}
$$

Bakteri yang bertanggung jawab untuk konversi ini adalah metanogen dan bekerja pada keadaan anaerob dengan jumlah oksigen kecil [15]. Bakteri methanogen sangat penting untuk proses anaerobik, karena bakteri methanogen akan tumbuh perlahan. Bakteri methanogen sangat sensitive terhadap perubahan temperatur lingkungan, bakteri methanogen dapat menyerap dan mencerna substrat yang paling sederhana. Beberapa dari spesies bakteri metanogen yang menonjol adalah bakteri methanobrevibacter ruminantium, bakteri $m$ bryantic dan bakteri thermoautotrophicum [16]. Bakteri penghasil metana dapat dibagi menjadi dua kelompok yaitu asetofilik dan hidrogenofilik. Asetofilik adalah proses produksi $\mathrm{CH}_{4}$ oleh dekarboksilasi asetat sedangkan hidrogenofilik memproduksi $\mathrm{CH}_{4}$ dengan cara mengurangi $\mathrm{H}_{2} / \mathrm{CO}_{2}$ [17].

Ada beberapa tahapan metanogenesis, setiap tahapan mengubah bahan pembuat menjadi $\mathrm{CH}_{4}$ dan substrat. Substrat utama yang digunakan dalam tahap ini adalah asam asetat $\left(\mathrm{CH}_{3} \mathrm{COOH}\right)$, asam metanoat $(\mathrm{HCOOH})$, karbon dioksida $\left(\mathrm{CO}_{2}\right)$, dimetil sulfat $\left.\left(\left(\mathrm{CH}_{3}\right) 2 \mathrm{SO}_{4}\right)\right)$, metanol $\left(\mathrm{CH}_{3} \mathrm{OH}\right)$, dan metilamin $\left(\mathrm{CH}_{3} \mathrm{NH}_{2}\right)$ [13].

Penelitian ini bertujuan untuk mengetahui efektifitas gas hasil biogas dengan variasi bahan biogas adalah kotoran sapi, dan kotoran sapi + ragi dengan perbandingan volume $3: 1$, kotoran sapi + ampas tebu dengan perbandingan volume 3:1 ditambah ragi tape 100 gram.

\subsection{Alat dan Bahan}

Dalam penelitian ini menggunakan kotoran sapi yang basah ditambah variasi penambahan ampas tebu. Kotoran sapi yang digunakan adalah sapi perah dan tebu yang digunakan adalah ampas tebu dari penjual minuman es tebu. Variasi bahan biogas adalah kotoran sapi 100\%, dan Ampas tebu:ragi dengan perbandingan volume 3:1, kotoran sapi + ampas tebu dengan perbandingan volume 3:1 ditambah ragi tape 100 gram.

Berat kotoran sapi yang mampu ditampung dalam alat biodigester sebesar $4 \mathrm{~kg}$. Tabung luar terbuat dari plastik kapasitas 60 liter, didalamnya dipasang tabung plastik yang digunakan untuk tempat kotoran sapi dan ditutup dengan plat alumunium dan diberi pipa laluan gas yang dipasangi kran. Tabung tempat bahan organik ditutup menggunakan tabung fermentasi aluminum yang berfungsi sebagai tempat berlangsungnya fermentasi dengan bantuan bakteri anaerob, tabung fermentasi digunakan agar memastikan kondisi didalam tabung tanpa udara serta berfungsi sebagai penampung biogas sementara. Saluran buang terhubung dengan plastik penampung biogas yang mampu menampung maksimal $5 \mathrm{M}^{3}$, seperti diperlihatkan pada Gambar 1.

Pencampuran bahan pembuatan biogas didalam tabung, agar sesuai dengan yang diinginkan. Ampas tebu sebaiknya dalam keadaan basah dan dicacah kecil kecil tidak beraturan. Pengambilan data yaitu kecepatan dalam menghasilkan biogas dalam digester dan dilakukan uji nyala untuk penyalaan kompor bahan bakar biogas dan petromak. Biogas yang dihasilkan memiliki komponen gas utama yaitu $\mathrm{CH} 4$ dan $\mathrm{CO}_{2}$, selain itu ada juga gas lain seperti $\mathrm{N}_{2}, \mathrm{H}_{2}, \mathrm{H}_{2} \mathrm{~S}$, atau $\mathrm{CO}$ dengan persentase kecil, seperti diperlihatkan pada Tabel 1 [18]

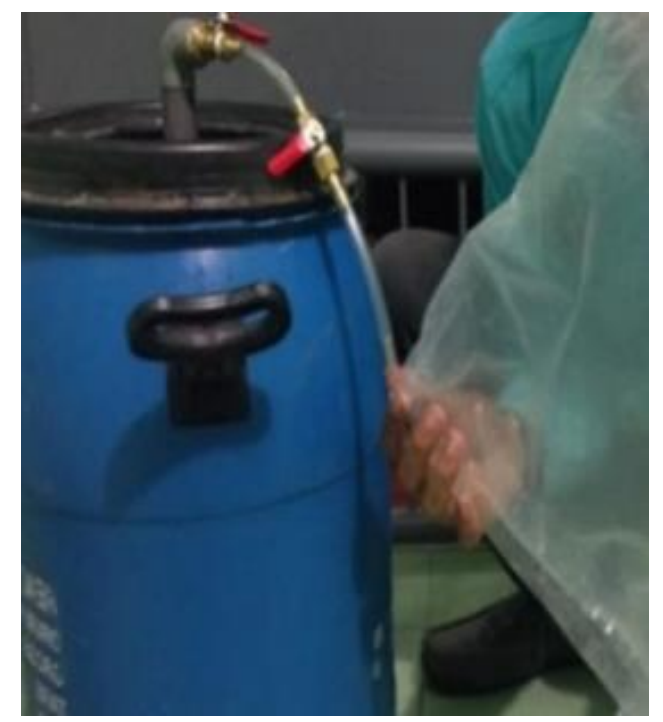

Gambar 1 Reaktor biogas portable.

Tabel 1. Penyusun biogas [19]

\begin{tabular}{lcc}
\hline Nama Penyusun & Formula & Konsentrasi \\
\hline Methane & $\mathrm{CH}_{4}$ & $40-75 \%$ \\
Karbon Dioksida & $\mathrm{CO}_{2}$ & $15-60 \%$ \\
Hidrogen & $\mathrm{H}_{2}$ & $<2$ \\
Hidrogen Sulfida & $\mathrm{H}_{2} \mathrm{~S}$ & $0-5000 \mathrm{ppm}$ \\
Oksigen & $\mathrm{O}_{2}$ & $<2$ \\
\hline
\end{tabular}




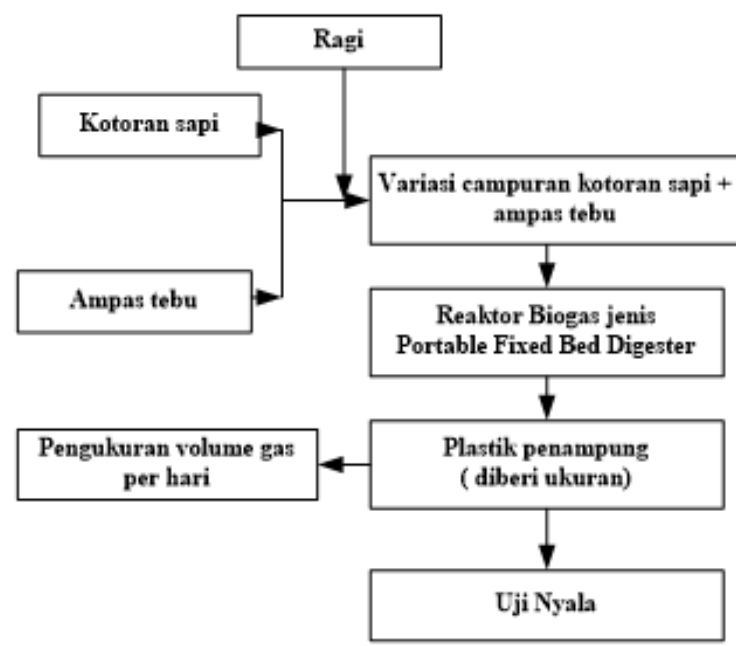

Gambar 2. Flowchart proses pengujian

Pada Gambar 2 menjelaskan mengenai proses pembuatan biogas dengan bahan baku kotoran sapi dan ampas tebu ditambahi ragi tape 100 gram. Pengambilan data yaitu jumlah pertambahan volume gas hasil di setiap variasi. Untuk meyakinkan bahawa gas yang dihasilkan mampu bakar maka dilakuan pembakaran gas setiap saat di setiap variasi.

\section{Hasil dan Pembahasan}

Reaktor yang dibuat seperti yang ditunjukkan pada gambar 1, memiliki beberapa bagian utama seperti inlet, outlet dan penyimpanan gas, perapat biar gas tidak keluar menggunakan air yang diisikan diantara dua tabung. Gas yang telah terbentuk di reaktor biogas akan keluar melalui outlet gas dan kemudian disimpan ke dalam penyimpanan gas. Reaktor biogas dilengkapi dengan manometer untuk mengukur tekanan di dalam digester. Data diperoleh dari pengujian 4 variasi terhadap hasil maksimal produksi gas perhari. Dilakukan pengamatan pada waktu pembentukan biogas. Dari hasil percobaan diperoleh bahwa ada perbedaan hasil biogas persatuan hari, pembentukan biogas antara kotoran sapi yang diberi starter berupa ragi tape dengan bahan yang tidak diberi ragi tape sebagai starter tambahan.

Pada Gambar 3 menjelaskan hasil biogas dari bahan pembuatnya, Kotoran sapi ditambah dengan ampas tebu dan di tambah dengan ragi tape lebih cepat menghasilkan biogas daripada bahan biogas dari kotoran sapi $100 \%$ yang tidak diberi tambahan apapun. Bahan kotoran sapi ditambah dengan ampas tebu dan ragi tape sangat cepat menghasilkan biogas dan jumlahnya sangat dignifikan terlihat digambar 3 pada hari ke 2 sudah menghasilkan biogas sebanyak 0.42 liter dan bila dibandingkan dengan variasi lain paling banyak hasilnya. Jumlah total biogas yang berasal dari bahan kotoran sapi ditambah dengan ampas tebu dan ragi tape paling banyak yaitu sebanyak 5.6 liter dalam 10 hari. Paling sedikit adalah dari $100 \%$ kotoran sapi yaitu 1.67 liter dalam 10 hari. Temperatur reaktor antara $32^{\circ} \mathrm{C}-36^{\circ} \mathrm{C}$ dan temperatur lingkungan antara $32^{\circ} \mathrm{C}-37^{\circ} \mathrm{C}$, pada temperatur tersebut diharapkan mempengaruhi mikroorganisme dalam beraktifitas untuk menghasilkan methan[10].
Temperatur yang baik dan ideal untuk produksi biogas adalah antara $32^{\circ} \mathrm{C}$ sampai dengan $37^{\circ} \mathrm{C}$, bila temperatur reaktor dibawah $30^{\circ} \mathrm{C}$ akan mengakibatkan proses fermentasi menjadi terhambat dan bila temperatur diatas $37^{\circ} \mathrm{C}$ maka reaktor biogas menjadi rusak [20]. Penggunaan campuran ampas tebu diharapkan mendukung bakteri mengubah glukosa menjadi asam asetat.

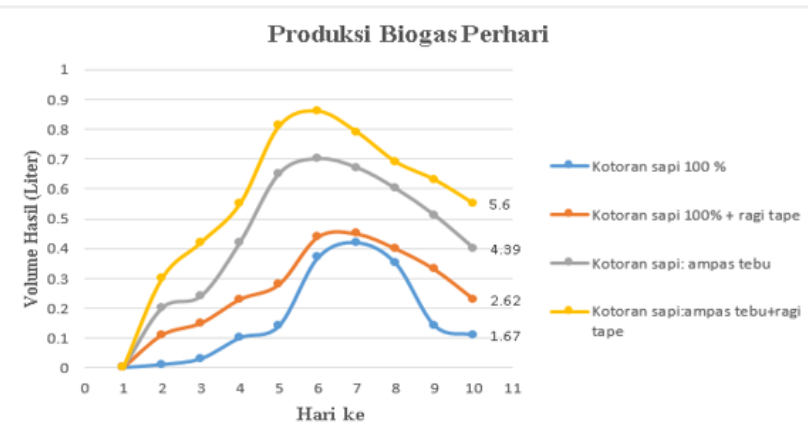

Gambar 3. Volume Biogas Dari 4 variasi per-hari

Tabel 2. Komposisi Bahan Pembuat Biogas [21]

\begin{tabular}{lc}
\hline Komposisi & Kotoran sapi \\
\hline Kadar air & 71,32 \\
Bahan kering & 28,68 \\
Total C (\%) & 39,87 \\
Total N (\%) & 1,42 \\
Rasio C/N & 28,08 \\
\hline
\end{tabular}

Melalui pemberian starter berupa ragi tape, akan ada peningkatan jumlah bakteri metanogenik. Jumlah bakteri bertambah membuat proses dekomposisi anaerob akan lebih cepat, sehingga biogas terbentuk lebih cepat daripada yang tidak diberi ragi tape. Ragi (saccharomyces cereviceae) merupakan berperan sebagai substrat activator dan dapat mempercepat proses degradasi senyawa kompleks yaitu polisakarida menjadi senyawa yang lebih sederhana. Proses degradasi yang lebih cepat dapat meningkatkan dan mempercepat tahapan pembentukan asam dan gas metan [22][23].

Kotoran sapi tanpa ditambahi ragi tape sebagai bahan pembuatan biogas membutuhkan waktu untuk pembentukan bakteri, proses dekomposisi anaerob membutuhkan waktu lebih lama, sehingga produksi biogas lebih lambat. Tetapi perlu diketahui bahwa ampas tebu merupakan bahan baku yang sangat sulit terdegradasi, yang mudah dan bersifat pensuplai komponen mikroba adalah kotoran sapi. Sehingga dalam percampuran lebih banyak kotoran sapi dari pada ampas tebu. Penurunan volume biogas dikarenakan semakin beratnya kerja mikroba mendegradai komponen bahan baku karena adanya penambahan komponen bahan baku yang sulit terdegradasi. Total solid akan berpengaruh terhadap proses inhibisi pada hidrolisis. Ruangan yang terbatas akan sangat menghambat proses transfer massa, akibatnya produk tahap hidrolisis mengumpul dipermukaan substrat dan dapat mengganggu penyerpan enzim hidrolitik. Terganggunya penyerapan dapat menurunkan produk dalam proses acidogenesis yang akan dikonversi menjadi biogas yang kaya akan methan. 
Kandungan Total solid secara berlebihan akan mengurangi volume biogas secara signifikan. Biogas diuji bakar, nyala api biru orange dan tidak mengeluarkan jelaga seperti terlihat pada Gambar 4.

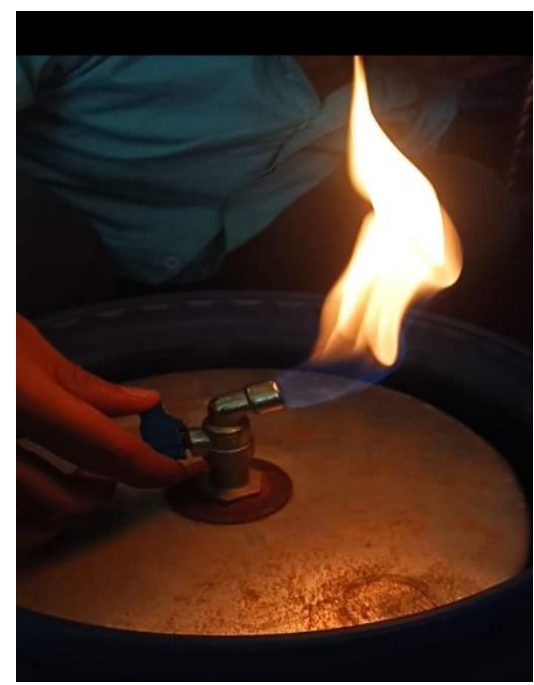

Gambar 4. Proses Nyala biogas yang dibakar.

\section{Kesimpulan}

Hasil biogas dari kombinasi ampas tebu dan kotoran sapi dapat diambil kesimpulan bahwa dengan pemberian starter berupa ragi tape, akan ada peningkatan jumlah bakteri metanogenik. Jumlah bakteri bertambah membuat proses dekomposisi anaerob akan lebih cepat, sehingga biogas terbentuk lebih cepat daripada yang tidak diberi ragi tape. Ampas tebu merupakan bahan baku yang sangat sulit terdegradasi, yang mudah dan bersifat pensuplai komponen mikroba adalah kotoran sapi. Total solid (TS) akan berpengaruh terhadap proses inhibisi pada hidrolisis.

Ruangan yang terbatas akan sangat menghambat proses transfer massa, akibatnya produk tahap hidrolisis mengumpul dipermukaan substrat dan dapat mengganggu penyerpan enzim hidrolitik. Terganggunya penyerapan dapat menurunkan produk dalam proses acidogenesis yang akan dikonversi menjadi biogas yang kaya akan methan. Kandungan total solid secara berlebihan akan mengurangi volume biogas secara signifikan.

\section{Daftar Pustaka}

[1] W. P. Dina Labiba, "Sebaran Emisi CO2 dan Implikasinya Terhadap Penataan Ruang Area Industri Di Kendal," $J$. Pengemb. Kota, vol. 6, no. 2, pp. 164-173, 2018.

[2] S. L. M. Meksy Dianawati, "Peluang Pengembangan Biogas Di Sentra Sapi Perah," J. Litbang, vol. 34, pp. 125-134, 2015.

[3] X. L. Shiwei Wang, Fang Ma, Weiwei Ma, Ping Wang, Guang Zhao, "Influence of Temperature ON Biogas Production Efficiency and Microbial Community in a Two Phase Anaerobic Digestion System," Water, vol. 11, no. 133, 2019.

[4] M. A. R Nandi, CK Saha, MS Huda, "Effect Of Mixing On Biogas Production From Cow Dung," Eco-Friendly Agril J, vol. 10, no. 02, pp. 07-13, 2017.

[5] M. Z. Fajri Azhari, Bunda Halang, "Kualitas Biogas Yang
Dihasilkan Dari Substrat Kotoran Sapi dan Penambahan Starter Buah-Buahan Dengan Menggunakan Digester Kubah," J. Wahana Bio, vol. XIV, 2015.

[6] B. H. Mashi, "Badiya (2018)Comparative Study of Biogas Production from Sugarcane Bagasse and Cow Dung.pdf," $J$. Microbiol. Res., vol. 3, no. 2, 2018.

[7] A. F. A Hadiyarto, D Soetrisnanto, I Rosyidin, "CODigestion of Bagasse and Waterhyacinth for Biogas Production With Variation of $\mathrm{C} / \mathrm{N}$ and Activated Sludge," $J$. Phys., 2019.

[8] W. S. Leandro Janke, Athaydes Leite, Marcell Nikolausz, Thomas Schmidt, Jan Liebetrau, Michael Nelles, "Leonardo Janke 2015.pdf," Mol. Sci., vol. 16, 2015.

[9] B. Siswo Sumardiono, Aldi Budi Riyanta, Hasfi Hawali Abdul Matin, Tutuk Djoko Kusworo, Bakti Jos, "Increasing Biogas Production From Sugar Cane Baggase By Anaerobic CO-Digestion With Animal manure," SiCEST, vol. 101, 2017.

[10] A. B. Riyanta, P. Harapan, and B. Tegal, "Biogas Kombinasi Ampas Tebu Kotoran Sapi Sebagai Upaya Konversi Energi Terbarukan," J. Para Pemikir, vol. 6, pp. 175-180, 2017.

[11] K. A. Neelam Vats, Abid Ali Khan, "Options For Enhanced Anaerobic Digestion of Waste," J. Biosyst. Eng., 2020.

[12] K. G. Anthony Anukan, Ali Mohammadi, Muhammad Naqvi, "A Review of The Chemistry of Anaerobic Digestion: Methods of Accelerating and Optimizing Process Efficiency," Processes, 2019.

[13] A. Anukam, A. Mohammadi, M. Naqvi, and K. Granström, "A Review of the Chemistry of Anaerobic Digestion: Methods of Accelerating and Optimizing Process Efficiency," Processes, vol. 7, no. 8, p. 504, 2019, doi: 10.3390/pr7080504.

[14] M. B. Ivan Kushkevych, Monika Vitezova, Tomas Vitez, "Production of Biogas: Relationship Between Methanogenic and Sulfate-Reducing Microorganisms," Open Life Sci, vol. 12, 2017.

[15] L. B. W. Jay N Meegoda, Brian Li, Kush Patel, "A Review of The Processes, Parameters,and Optimization of Anaerobic Digestion," Int. J. Environ. Res. Public Health, vol. 15, 2018.

[16] B. M. Shahid Manzoor, Anna Schnurer, Erik Bongcam Rudloff, "Complete Genome Sequence of Methanoculleus Bourgensis Strain MAB1, The Syntrophic Partner Of Mesophilic Acetate-Oxidising Bacteria (SAOB)," Stand. Genomic Sci., pp. 2-9, 2016.

[17] S. C. Ramansu Goswami, Pritam Chattopadhyay, Arunima Shome, Sambhu Nath Banerjee, Amit Kumar Chakraborty, Anil K Mathew, "An Overview Of Physico-Chemical Mechanisms of Biogas Production by MIcrobial Communities: A Step To Wards Sustaainable Waste Management," 3 Biotech, vol. 6, no. 7, 2016.

[18] N. L. Olumide Wesley Awe, Yaqian Zhao, Ange Nzihou, Doan Pham Minh, "A Review of Biogas Utilisation, Purification And Upgrading Technologies," HAL Arch. outvertes, 2018.

[19] B. Bharathiraja, T. Sudharsana, J. Jayamuthunagai, R. Praveenkumar, S. Chozhavendhan, and J. Iyyappan, "Biogas production - A review on composition, fuel properties, feed stock and principles of anaerobic digestion," Renew. Sustain. Energy Rev., vol. 90, no. April, pp. 570-582, 2018, doi: 10.1016/j.rser.2018.03.093.

[20] D. Agusman, R. Rifky, and A. K. Buono, "Pengaruh Starter Ragi dalam Proses Pembentukan Biogas Limbah Buah," Pros. Semin. Nas. Teknoka, vol. 2, no. 2502, pp. M37-M43, 2017.

[21] C. Afrian, A. Haryanto, U. Hasanudin, and I. Zulkarnain, 
"PRODUKSI BIOGAS DARI CAMPURAN KOTORAN SAPI DENGAN RUMPUT GAJAH ( Pennisetum purpureum ) [ PRODUCTION OF BIOGAS FROM A MIXTURE OF COWDUNG AND ELEPHANT GRASS ( Pennisetum purpureum ) ]," J. Tek. Pertan. Lampung, vol. 6, no. 1, pp. 23-30, 2017.

[22] Badiyya Hassan Mashi, "Comparative Study of Biogas Production From Sugarcane Bagasse and Cow Dung," UMYU J. Microbiol. Reseach, vol. 3, no. 2, pp. 127-132, 2018.
[23] A. M. Ritonga and A. M. Ritonga, "JURNAL RONA TEKNIK PERTANIAN Optimasi Kandungan Metana ( $\mathrm{CH}$ 4 ) Biogas Kotoran Sapi Menggunakan Berbagai Jenis Adsorben Program Studi Teknik Pertanian, Fakultas Pertanian , Universitas Jenderal Soedirman Optimization Of Methana Content ( CH4 ) Biogas of," J. Rona Tek. Pertan., vol. 10, no. 2, 2017. 